Tomasz P. Górski

Wrocław

\title{
TŁUMACZ JAKO ŹRÓDŁO NIEPRZETKUMACZALNOŚCI
}

\footnotetext{
Zarys treści. W tekście podjęto próbę omówienia zagadnienia nieprzetłumaczalności, której źródłem jest osoba tłumacza. Wychodząc z założenia, że proces tłumaczenia tekstu jest aktem subiektywnej interpretacji tekstu źródłowego, dokonywanej przez przekładowcę, autor wysuwa tezę, że ograniczenia zdolności poznawczych tłumacza oraz jego compléments cognitifs mogą doprowadzić do nieprzetłumaczalności.
}

Wszyscy jesteśmy fotografami posługującymi się zmienną ogniskową. Dzięki tej właściwości, poruszając pierścieniem obiektywu, możemy obraz każdego obiektu czy sceny powiększyć lub zmniejszyć, wyodrębnić albo pominąć. Za pomocą tego właśnie mechanizmu manipulujemy obrazami świata. Jedne utrwalamy, inne skazujemy na niebyt. Ale ponieważ każdy w każdej chwili i miejscu ciągle tą zmienną porusza i przestawia, każda rzecz wygląda na milion sposobów - różnie - i w związku z tym na tych milion sposobów jest również widziana i przeżywana.

Ryszard Kapuściński, Lapidarium V, cyt. za: Tabakowska (2004: 47).

\section{Preliminaria}

$\mathrm{N}_{\mathrm{i}}$ ieprzetlumaczalność jest immanentnym elementem procesu przekładu i zdaje się być jednym z podstawowych problemów poruszanych w rozmaitych badaniach komparatystycznych. W swojej najbardziej radykalnej formie problem nieprzetłumaczalności ilustrują poglądy Sapira i Whorfa, traktujące język jako pochodną kultury, z którą współtworzy on osobowość 
swych użytkowników. Poglądy te implikują ponadto, że repertuar środków służących do wyrażenia myśli w danym języku jest unikalny i niepowtarzalny, co w konsekwencji prowadzi do tezy o wzajemnej nieprzekładalności poszczególnych języków w sensie absolutnym (por. Wille 2002). Chociaż hipoteza Sapira i Whorfa została podważona przez późniejsze prace uniwersalistów, problem nieprzetłumaczalności i kulturowego zdeterminowania języków jest ciągle obecny jako kluczowy aspekt komunikacji między ludźmi za pośrednictwem języka pomimo różnorodności systemów językowych.

\section{Granice nieprzetłumaczalności i ekwiwalencja}

Refleksja nad nieprzetłumaczalnością i jej granicami biegnie dwoma torami w zależności od przyjętego kryterium badania tego zjawiska. Analizując wyłącznie aspekt językowy i ekwiwalencję oryginału w stosunku do tłumaczenia na poziomie języka dochodzimy do wniosku, że nieprzystawalność języków nawet blisko spokrewnionych osiąga bardzo wysoki poziom i w konsekwencji kompletne oddanie językowej treści komunikatu staje się niemożliwe. Aspekt kulturowego nacechowania języka odgrywa tutaj rolę wtórną, ponieważ przedmiotem badania są języki jako wytwory kultury i zarazem ich integralne części, a akcent badania pada na znalezienie ich cech wspólnych oraz jednakowych uwarunkowań gramatycznych. Ekwiwalencja zawsze więc będzie niepełna, a całkowita tożsamość oryginału i przekładu stanie się pojęciem czysto teoretycznym. Drugim założeniem jest odczytanie sensu poprzez interpretację relacji semantycznych w tekście i oddanie ich w języku docelowym, co stanowi właściwy przedmiot praktyki przekładowczej. W tym przypadku tłumacz zmuszony jest do kreatywnej eksploatacji zasobów własnego języka, uwzględnienia warunków, w jakich przekład ma funkcjonować w określonej sytuacji pragmatycznej, interpretacji sensów oryginału w celu właściwego ich przekazania w języku docelowym.

Kompilując oba podejścia zagadnienia nieprzetłumaczalności i biorąc pod uwagę zróżnicowanie języków oraz rozmaite typy tekstów i funkcje, jakie mają one spełnić, proces przekładu staje się praktyką interpretacyjną, w której tłumacz występuje w funkcji dwujęzycznego mediatora odpowiedzialnego za właściwe odczytanie obcojęzycznego komunikatu oraz zanurzenie go w kontekst gramatyki komunikacyjnej języka obcego (por. Górski $\mathrm{i}$ in. 2003). 


\section{Przekład jako interpretacja}

Twierdzenie, że każdy tekst jest odczytywany subiektywnie nie budzi we współczesnej myśli translatorycznej wątpliwości. Takie odczytanie oryginału i nadanie mu znaczeń prowadzi do ujawnienia ważnej cechy procesu przekładu: każdy przekład, a w szczególności operacja przekładu tekstu literackiego, jest interpretacją oryginału (por. m.in. Newmark 1995: 98, 127). Pomimo że wielu badaczy wyraźnie oddziela te terminy, przeciwstawiając się traktowaniu ich synonimicznie (np. Dąmbska-Prokop 2000: 100-101), odrzucamy tutaj to stanowisko z dwóch głównych powodów. Po pierwsze - przez interpretację rozumiemy kompleksowe odczytanie komunikatu tekstowego, a więc jest to wstępny etap procesu jego przekładu. Po drugie, jak zauważa Marilyn Rose, jest to pewna forma krytyki tego komunikatu, gdyż polega na transferze cech dystynktywnych (ang. distinctive features) tekstu do innego języka, a zatem staje się aktem derywacji elementów z oryginału do przekładu (por. Rose 1997: 13). W świetle tego interpretacją staje się wyselekcjonowanie owych cech dystynktywnych i zakotwiczenie ich w kontekście języka i kultury docelowej na podstawie prognostycznej analizy tej kultury oraz dzięki zastosowaniu ekwiwalentów funkcyjnych (por. Tokarz 1998: 65). Przetłumaczony, a więc odpowiednio zinterpretowany tekst staje się fenomenem nowej kultury, którego początek Roger Bell widzi w uważnym i dokładnym czytaniu oryginału:

przetłumaczony tekst jest aktem nowego tworzenia wywodzącego się z uważnego i dokładnego czytania; jest raczej rekonstrukcją niż kopią. (Bell 1991: 161; tłum. T. G., wyróżnienie autora).

W myśl powyższego przekład jest zabiegiem polegającym na interpretacji tekstu źródłowego i odpowiednim wyrażeniu tego tekstu w innym języku, przy czym jest to proces mentalny, skupiony w osobie tłumacza. Pierwszym etapem tego procesu jest analiza tekstu źródłowego i określenie jego wartości komunikacyjnej. W jego wyniku w umyśle tłumacza powstaje reprezentacja semantyczna tego tekstu; innymi słowy - zbiór znaczeń subiektywnie nadanych znakom tekstowym. Reprezentacja semantyczna z kolei ulega syntezie (chronotopowemu - w sensie Bachtinowskim, por. niżej - i jednocześnie selektywnemu połączeniu) w nową całość, której efektem staje się tekst tłumaczenia wpisany w kontekst kultury docelowej. 
Zgodnie z powyższym interpretacja jawi się nam jako immanentny składnik każdego aktu czytania, określenia potencjału znaczeniowego komunikatu tekstowego, a także ważny element determinujący zakotwiczenie kulturowe tekstu przekładu. W przypadku utworów poetyckich, których istotnymi wyróżnikami są dwuznaczność i niedookreśloność, pozwalające na szeroki wachlarz możliwych odczytań, interpretacja odgrywa zasadniczą rolę warunkującą sam proces tłumaczenia, będąc jednocześnie nieodzowną jej częścią.

"Żadne tłumaczenie - pisze Sukanta Chaudhuri (2000: 22) - nie pozostaje obojętne na różnice kulturowe" (tłum. T. G.). Poszerzając tę konstatację o wyniki rozmaitych badań komparatystycznych (np. Catford 1965) oraz analizę samego procesu tłumaczenia, dochodzimy do wniosku, że dostosowanie komunikatu obcojęzycznego do środowiska nowego języka oraz właściwe wyrażenie jego wartości komunikacyjnej pociąga za sobą sporo zmian na wszystkich jego poziomach: konstrukcyjnym, semantycznym, fonetycznym, konotacyjnym etc. Zmiany te mogą mieć źródło w odmienności języków (ich nieprzystawalności), wypływają zatem z materiału badawczego, lecz dodatkowym, równie ważnym czynnikiem jest specyfika samego procesu tłumaczenia, a ściślej - niemożliwość oddania wszystkich elementów kompleksowej struktury oryginału. Część jego komponentów ginie, innym nadane zostają odmienne cechy aksjologiczne, a wszystkie one zależą od strategii przekładu obranej przez tłumacza i sposobu, w jaki rozumie on tekst oryginalny.

Zadaniem tłumacza jest ni mniej, ni więcej jak oddanie tekstu źródłowego, interpretacja danej myśli autora oryginalnego, wyrażonej w pewnej liczbie odmian i dostępnej czytelnikom nieznającym tych odmian poprzez zastąpienie wersji przedstawionej przez autora oryginalnego w innym języku, czasie, miejscu i tradycji. Szczególną uwagę należy zwrócić na fakt, że tłumacz musi zastąpić ekwiwalentami wszystkie jej odmiany zawarte w tekście źródłowym. (A. Lefevere 1975: 91; tłum. T. G., wyróżnienie autora).

Innymi słowy zrozumienie oryginału jest obrazem kategoryzacji fragmentu przedstawionego $\mathrm{w}$ nim świata dokonanym przez tłumacza.

\section{Czym jest tekst?}

Omówienie specyfiki procesu przekładu ogniskuje się zawsze na problemie tekstu, gdyż to właśnie on jest podstawowym materiałem znaczeniono- 
śnym biorącym udział $\mathrm{w}$ tym procesie. $\mathrm{Z}$ naszej perspektywy istotne jest postrzeganie tekstu jako konstruktu, który nie ma stałego znaczenia, więc jego charakterystyczną cechą jest wielość możliwych i tym samym poprawnych sposobów interpretacji. Oba te założenia są konsekwencją specyficznego ujęcia tekstu opracowanego przez Umberta Eco: autor - nadawca komunikatu tekstowego - jest jedynie inicjatorem procesu jego konstrukcji, gdyż w myśl koncepcji opera aperta zadaniem czytelnika (odbiorcy) jest dokończenie owego komunikatu lub też jego proliferacja. Czytelnik postrzegany jest więc jako współautor powstającego dzieła, a kiedy rozpoczyna się proces jego czytania, autor traci do tego tekstu praktycznie wszystkie swoje prawa (por. Sieńko [1997] 2003), panując jednak - jako jednostka inteligentna (por. Pavel 1989: 266) - nad każdym jego odczytaniem. Założeniem konstrukcyjnym i semantycznym tak pojętego komunikatu tekstowego staje się wieloznaczność, nieokreśloność oraz niemożliwość odczytania całego potencjału semantycznego podczas indywidualnego aktu jego analizy. Istnienie tekstu jest zatem uwarunkowane obecnością odbiorcy, który - jako jego współautor - jest jednocześnie jego interpretatorem: wpisuje go w ramę swoich oczekiwań tekstowych, sytuuje go w przestrzeni intertekstualnej, a do indywidualnych skojarzeń wykorzystuje własne compléments cognitifs (tj. w ogólnym ujęciu wiedza pozajęzykowa oraz umiejętność odczytania i zrozumienia znaczeń tekstu/dyskursu), łącząc w ten sposób poszczególne jego jednostki w większe tekstowe całości. Na otwartość tekstów oryginalnych zwraca również uwagę Bożena Tokarz; według niej jest to cecha oryginału pozwalająca na „zajmowanie [przez czytelnika i tłumacza - T. G.] różnych postaw interpretacyjnych, które wynikają z odmiennej - w każdym języku, kulturze i czasie - perspektywy oglądu" (Tokarz 1998: 5). Użyty tutaj termin „perspektywa oglądu”, jak się okazuje, jest bardzo zbliżony (jeśli nie identyczny) z przyjętym przez interpretatora indywidualnym punktem odniesienia, a więc jego chronotopem.

\section{Chronotop}

Czym jest chronotop? Jak wynika z koncepcji Bachtina, chronotop to czasowo-przestrzenny punkt odniesienia, którego odbiorca tekstu używa podczas procesu czytania i interpretacji każdego komunikatu tekstowego. Ponieważ chronotop jest wartością subiektywną i inną dla każdego jednostkowego odczytania tekstu, zarówno podczas czytania pierwotnego (tj. czytania oryginału), jak i wtórnego (czytania przetłumaczonego tekstu), odbiorcy dzia- 
łają w perspektywie odmiennego chronotopu. W konsekwencji doprowadza to do przeprowadzenia odmiennych analiz nawet w przypadku, kiedy interpretacja dotyczy tego samego tekstu i wykonuje ją ta sama osoba.

Chronotop pozwala czytelnikowi (a więc również tłumaczowi) na dokonanie interpretacji komunikatu tekstowego. Umożliwia on jednak odczytanie i przekazanie w innym języku wyłącznie znaczeń temporalnych, tzn. tych, które aktualizują się i ujawniają jedynie w momencie jego analizy. $\mathrm{Z}$ tego powodu oryginał nigdy nie może być w pełni zaktualizowany semantycznie podczas indywidualnego aktu czytania, a przekład ujawni jedynie jednostkowe i temporalne znaczenia zgodnie z obraną przez tłumacza strategią tłumaczenia (por. Tokarz 1998: 69).

Konceptualizacja tekstu i intencja komunikacyjna

Porównując oryginał z jego przekładem pod względem konceptualnym, dochodzimy do wniosku, że oba te teksty są realizacją tej samej idei tekstu (intencji komunikacyjnej), a przekład w tej perspektywie można określić jako replikę oryginału. Replika ta jednakże nie staje się idealnym odbiciem tekstu oryginalnego, zbliża się jedynie do niego lub oddala, podobnie jak stereotyp od postaci prototypowej, lecz nigdy nie jest z nim tożsama. Dzieje się tak, dlatego że zarówno oryginał, jak i przekład są wynikiem odmiennych konceptualizacji tego samego konceptu językowego opartego na odmiennych doświadczeniach nadawców obu komunikatów. Można zatem w świetle tego rozpatrywać oryginał i przekład jako „podwójność realizacji” (Tokarz 1998: 21) tego samego konceptu (szerzej na temat por. Tokarz 1998: 21-26). Interesująco zagadnienie to w świetle językoznawstwa kognitywnego omawia Elżbieta Tabakowska (por. m.in. Tabakowska 1991; [1993] 2001).

Z komparatystycznego i translatologicznego punktu widzenia uzależnienie przekładu od oryginału ma istotną zaletę: pozwala ono na określenie stopnia ekwiwalencji między tymi dwoma tekstami oraz opisanie właściwych im zakotwiczeń sytuacyjno-pragmatycznych. Faktem bezspornym jest, że przetłumaczony tekst nie stanowi wiernego odbicia oryginału, lecz jego aproksymację, zanurzoną w odpowiedni kontekst kultury języka docelowego. Wysnuć można $\mathrm{z}$ tego słuszny wniosek, że oryginał i przekład to nie teksty tożsame, lecz jedynie ekwiwalentne, zbliżone, pomiędzy którymi istnieje wiele różnic. Ich właściwe określenie i opisanie jest zwykle głównym celem badań porównawczych. Dlatego też na tekst przekładu na- 
leży patrzeć przez pryzmat tekstu oryginalnego: pozwoli to na zachowanie jego statusu tekstu niesamodzielnego (uzależnionego) oraz - w konsekwencji - pokazanie różnic wywołanych zmianą zanurzenia pragmatycznego i kontekstu wypowiadania w języku docelowym.

\section{Nieprzetłumaczalność i tłumacz}

Reasumując - tekst jest w naszym ujęciu tworem o znaczeniu pluralnym, przy czym każde jego znaczenie zostaje ujawnione podczas pojedynczego aktu czytania/interpretacji. Interpretacji dokonuje oczywiście tłumacz, a ponieważ działa on na podstawie własnego chronotopu, jego odczytanie/ zrozumienie/interpretacja tekstu oryginalnego jest pochodną umysłowych procesów poznawczych, wykazujących indywidualne zróżnicowania. Każdy tłumacz bowiem konceptualizuje daną scenę subiektywnie, ponieważ każdy z nich posiada inny potencjał poznawczy, inną wiedzę aprioryczną, a także wykorzystuje inny zasób słownictwa do zwerbalizowania komunikatu w innym języku; w ten sam sposób wybiera on także odpowiednie konstrukcje gramatyczne. Zawrzeć to można w często powtarzanej przez wielu tłumaczy formule: TAK TO ROZUMIEM, TAKIE TO MA DLA MNIE ZNACZENIE, TEN SPOSÓB ROZUMIENIA JEST DLA MNIE NAJWŁAŚCIWSZY I DLATEGO TAK WYGLĄDA MOJA WERSJA PRZEKŁADU. Nie są to sytuacje marginalne i odosobnione, chociaż wiadomo, że zwykle wybór odpowiednich struktur gramatycznych i organizacja słowno-znaczeniowa są podporządkowane warunkom spójności tekstu; ponad wszelką wątpliwość istnieją preferowane sposoby widzenia świata uwarunkowane społecznie i kulturowo oraz norma języka, dzięki którym pewne pojęcia przybierają skonwencjonalizowany kształt językowy. Jednak w sytuacji, w której konceptualizacja sceny oryginału u tłumacza przebiegła w sposób, który nie pozwala na oddanie danego komunikatu w innym języku, mamy do czynienia z nieprzetłumaczalnością. Nie jest to wynik niekompetencji tłumacza, lecz raczej ograniczenie mające źródło w specyficznej konstrukcji jego potencjału poznawczego, a więc compléments cognitifs. Często problem tego typu obserwujemy na przykładzie tłumaczenia metafory: pomimo wysokiej kompetencji tłumacza w momencie dokonywania przekładu nie jest on w stanie znaleźć określenia na sformułowanie oryginalne, a więc zastępuje je innym (zbliżonym, nieekwiwalentnym), określając jednocześnie to pierwsze jako nieprzekładalne. Jest to zatem nieprzekładalność względna i nie wynika ze specyfiki samego oryginalnego sformułowania: używając 
Bachtinowskiego terminu - chronotop przyjęty przez tłumacza nie pozwala mu na przekazanie treści obcojęzycznej. Tłumacz ucieka się zatem do parafrazy, omówienia, przesunięcia semantycznego bądź też, w skrajnych przypadkach, opuszcza tę treść, traktując ją jako nieprzetłumaczalną. Chronotop innego tłumacza może z kolei tę treść ujawnić, gdyż jego compléments cognitifs pozwalają na jej odczytanie i werbalizację w innym języku. Podkreślmy jeszcze raz - źródłem nieprzetłumaczalności w takiej sytuacji jest tłumacz, a ściślej - procesy poznawcze i mentalne, na które nie ma on bezpośredniego wpływu. Możliwe staje się poszerzenie wiedzy umożliwiające odczytanie tekstu oryginalnego, lecz za każdym razem będzie to odczytanie jednostkowe i subiektywne. Będzie to znaczenie, które tłumacz ( $\mathrm{tj}$. czytelnik oryginału), w myśl koncepcji Eco niejako „negocjuje” z autorem, ale też znaczenie, jakie postuluje współczesne językoznawstwo kognitywne, czyli to, co wynika z kategoryzacji świata i sposobu, w jaki go widzimy.

\section{Wnioski}

Stosunkowo trudno jest podać praktyczne wnioski wynikające z tego stanowiska. Jedynym sposobem analizy tego zagadnienia wydaje się opinia tłumacza, który musiałby sam zdecydować o tym, co było powodem nieprzetłumaczalności: przyjęty przez niego świadomie bądź nieświadomie chronotop, towarzyszące każdemu procesowi przekładu ograniczenia języka czy też jego niedostateczna kompetencja w zakresie języka i kultury oryginału bądź przekładu. Pewien jestem jednak, że świadomość „niedoskonałości”, czyli - parafrazując słowa Kapuścińskiego użyte jako motto - odmienne oglądanie i przeżywanie każdej rzeczy może ujawnić wiele faktów, o których współczesna translatoryka ciągle milczy. Co jednak bardziej interesujące - przyznając tłumaczom prawo do odmiennego postrzegania znaczenia oryginału, musimy istnienie zjawiska nieprzetłumaczalności podać w wątpliwość. Tutaj jednak, w kontekście niniejszego wywodu, trzeba zawiesić głos, pozostawiając ostateczną decyzję kompetencji samych przeładowców, dając im jednocześnie powód do autorefleksji. 


\section{Literatura}

Bell, R. T., 1991, Translation and Translating: Theory and Practice, London. Catford, J. C., 1965, A Linguistic Theory of Translation, Oxford.

Dąmbska-Prokop Urszula (red.), 2000, Mała encyklopedia przekładoznawstwa, Częstochowa.

Chaudhuri, S., 2002, Translation and Understanding, Oxford.

Górski, T. P. i in., 2003, „O pragmatycznej nieprzekładalności w interkulturowych gramatykach komunikacyjnych", [w:] Dialog kultur w Nowej Europie. Historia. Literatura. Język, red. K. Iwan i in., Szczecin, s. 218-226. Lefevre A., 1975, Translating Poetry. Seven Strategies and a Blueprint, Assen. Newmark, P., 1995, Approaches to translation, New York.

Pavel, Th. G., 1989, „Racine and Stendhal”, [w:] Yale French Studies. Autour de Racine: Studies in Intertextuality, No. 76, s. 265-283.

Rose, M. G., 1997, Translation and Literary Criticism, Manchester.

Sieńko, M., 2003, „Interpretacja i nadinterpretacja, czyli o uprawnieniach czytelnika", dok. elektr.: http://simon.hell.pl/ecol.html

Tabakowska, E., 1991, „Przekład i obrazowanie”, Arka, 34 (4), s. 52-60.

Tabakowska, E. [1993], 2001, Językoznawstwo kognitywne a poetyka przekła$d u$, Kraków: Universitas.

Tabakowska, E., 2004, „O językowych wyznacznikach punktu widzenia”, [w:] Punkt widzenia w języku i w kulturze, red. J. Bartmiński i in., Lublin, s. 47-64. Tokarz, B., 1998, Wzorzec, podobieństwo, przypominanie, Katowice. Wille, L., 2002, Uniwersalistyczne implikacje teorii przekładu, Rzeszów.

\section{Translator-centred untranslatability}

(summary)

The article attempts at analysing the notion of translator-centred untranslatability, i.e. untranslatability that has its source in the translator. The author starts his discussion with the statement that the process of translation is an act of subjective interpretation of the source text performed by the translator, and then he puts forward the thesis that the limits of the translator's cognitive potency and his compléments cognitifs may lead to phenomena referred to as untranslatability. 